INTERDISCIPLINARIA ARCHAEOLOGICA NATURAL SCIENCES IN ARCHAEOLOGY

\title{
Traumatic Injuries in the Late Medieval and Early Modern Population from Łekno, Poland
}

\author{
Anna Myszka ${ }^{\mathrm{a}^{*}}$, Janusz Piontek ${ }^{\mathrm{a}}$, Elżbieta Miłosz ${ }^{\mathrm{a}}$ \\ ${ }^{a}$ Department of Human Evolutionary Anthropology, Institute of Anthropology, Adam Mickiewicz University, Poland
}

\section{ARTICLE INFO}

\section{Article history:}

Received: 7. November 2012

Accepted: 17. January 2013

\section{Key words:}

physical anthropology

traumatic injuries

bone

medieval population

\begin{abstract}
$A B S T R A C T$
The aim of this study was to document the traumatic injuries in the late medieval and early modern population from Łekno, Poland $\left(13^{\text {th }}-16^{\text {th }}\right.$ centuries AD). The authors studied 247 skeletons (147 males; 81 females; 19 unsexed individuals).

In a first step, tauma prevalence rate was calculated with reference to the number of individual skeletons affected. These data were compared with the data from other Polish skeletal series (Cedynia, Czersk, Złota Pińczowska, Toruń, Słaboszewo, Doktorce).

Traumatic injury frequencies in Łekno poulation were also calculated with reference to the long bones (clavicula, humerus, radius, femur, tibia, fibula). The obtained results were compared with the simillar data from the selected populations from Central Europe - Slavonic population from the Czech Republic (Pohansko u Břeclavi; $8^{\text {th }}-10^{\text {th }}$ centuries AD) (Kanášová et al. 2009), late medieval - early modern $\left(11^{\text {th }}-19^{\text {th }}\right.$ centuries AD) populations from Serbia (Velemirovi Drovi, Stara Torina, Dići, Čačak, Valjevska Gračanica, Žiča) (Djurić et al. 2006) and a medieval (13 ${ }^{\text {th }}-14^{\text {th }}$ centuries AD) population from Croatia (Kaprivno) (Novak 2011).

The frequency of injuries in the Łekno population was $12.1 \%$. The bones with most frequent evidence of trauma were clavicula and ulna. According to injuries the Lekno population does not differ from the population from Doktorce, Słaboszewo, Torun, but it does differ from populations from Czersk, Cedynia, Złota Pińczowska. The Łekno population does not differ from the populations from the Czech Republic and Croatia.
\end{abstract}

\section{Introduction}

Trauma may be defined as an injury to living tissue that is caused by force or a mechanism extrinsic to the body (Lovell 1997). Evidence for skeletal trauma is common in the remains of past people (Paine et al. 2007). Traumatic lesions are markers used to reconstruct past life-styles from the skeleton (Brasili et al. 2004; Grauer, Roberts 1996; Neves et al. 1999). The location, structure, conformation and degree of healing of injuries can inform us about their etiology, events that might have caused them and possible treatments (Jurmain 2001). They provide useful information about occupational, behavioral, socio-cultural and even environmental aspects of the individuals' and populations' lives (Judd 2002; Judd, Roberts 1999; Larsen 1987, 1997; Lovejoy,

"Corresponding author. E-mail: myszanka@amu.edu.pl
Haiple 1981; Ortner, Putschar 1981; Scott, Buckley 2010). A number of studies demonstrate that factors like interpersonal violence (Šlaus, Novak 2006), age, reduced bone mass due to inactivity, poor health predisposition, geographic location, climate, technological level, occupation or domestic activity play an important role in fracture etiology (Judd, Roberts 1998; Ortner, Putschar 1981). Traumatic injuries, as cross-cultural phenomena, provide an opportunity to make inter- and intra-populational comparisons, and thereby can add to the knowledge about the activity, demographic distribution, occupation, living conditions, health of investigated individuals and/or populations (Brasili et al. 2004; Judd, Roberts 1998).

The purpose of this paper is to document the prevalence of traumas identified in the late medieval and early modern population from Łekno, Poland. The results obtained for the Łekno population were compared with results obtained for other populations from the area of Poland and for selected populations from Central Europe. 


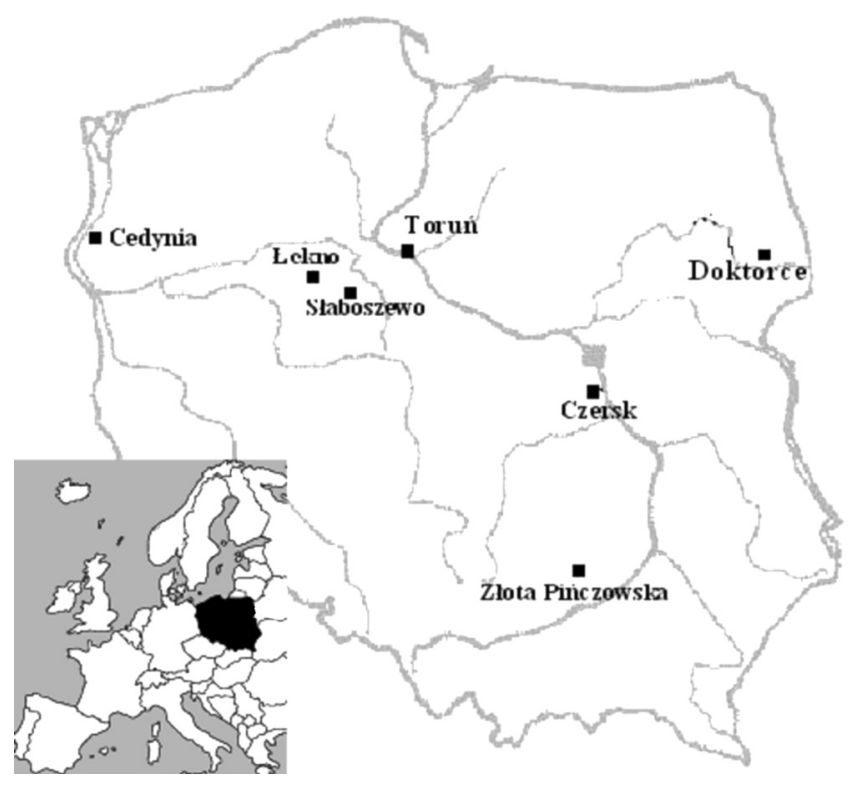

Figure 1. Location of investigated Polish cemetery sites.

\section{Materials and Methods}

The human remains examined in this study come from the Łekno cemetery site. The skeletons come from a skeletal site with layered graves, which was in use from the end of the $13^{\text {th }}$ century till the beginning of the $16^{\text {th }}$ century (Wyrwa 2003).

Łekno was a part of the so-called Łekno settlement complex, with the central part in the area surrounding Lake Łekno, where in historical times settlements and architectural structures of considerable political, administrative, socio-economic and religious significance were located (Wyrwa 1989).

Skeletons of 247 individuals were examined (including 147 males, 81 females, and 19 unsexed individuals). The group under study included 16 juveniles and 231 adults. Since traumatic injuries were noted only in adult individuals, all analyses were conducted for the whole population, including both juveniles and adults.

Recommended methods were applied to estimate the age and sex of the individuals (Ferembach et al. 1979; Buikstra and Ubelaker 1994). Characteristics of the cranium and pelvis were assessed for sex estimation. The age was determined through the analysis of the degree of cranial suture obliteration, changes on the surface of pubic symphysis and the degree of dental crown attrition.

In the first step trauma prevalence rate was calculated with reference to the number of individual skeletons affected ${ }^{1}$ ([number of skeletons affected/number of examined

${ }^{1}$ Due to a small sample size and because of inconsistencies in the description and interpretation of trauma in anthropological literature (Djurić et al. 2006; Lovell 1997), no categorization of traumatic injuries into specific types (e.g., fracture, dislocation, post-traumatic deformity, miscalcaneous traumatic conditions (Ortner, Putschar 1981); intentional and accidental (Larsen 1997); direct, indirect trauma; fracture, dislocation (Guikstra, Ubelaker 1994; Lovell 1997); etc.) was used in this study. individuals $] \times 100$ ). The significance of the differences between males and females according to traumatic inuries frequencies was tested by the test for two components of the structure. Data from the Łekno population was compared with the data from other Polish skeletal series (Cedynia, Czersk, Złota Pińczowska, Toruń, Słaboszewo, Doktorce). The significance of the differences between populations according to traumatic inuries frequencies was tested by the test for two components of the structure. The locations of the investigated Polish sites are shown in Figure 1.

Cedynia: a cemetery site dated back to the period from the second half of the 10th century till the first half of the $14^{\text {th }}$ century AD (Malinowska-Łazarczyk 1982). Data on the frequency of traumas for the site come from an unpublished study by Abramczuk (1993). A rural population (Porzeziński 2006).

Zlota Pińczowska: a cemetery site dated back to the $11^{\text {th }}$ $12^{\text {th }}$ century AD (Wiercińska 1980). Data on bone injuries were compiled by Komitowski (1975). A rural population (Miśkiewicz 1967, 1968; Wiercińska 1980).

Czersk: a cemetery site dated back to the period from the $11^{\text {th }}$ to $13^{\text {th }}$ century AD (Rauhut 1976). Data on the frequency of injuries were presented by Gładykowska-Rzeczycka (1976, 1978). An early urban population (Rauhut 1976).

Toruń: a cemetery site used in the $12^{\text {th }}-16^{\text {th }}$ centuries AD. Data on the traumatic injuries were compiled by Jakubowska and Kozłowski (2011). Urban population (Kozłowski et al. 2011).

Slaboszewo: a cemetery site dated back to the period from the second half of the $14^{\text {th }}$ century to the first half of the $17^{\text {th }}$ century AD (Piekarz, Piontek 1999). Data on the injuries in this population are available in the study by Tukałło et al. (1974). A rural population (Piontek, Henneberg 1981).

Doktorce: a rural medieval population. Data on bone injuries were compiled by Gładykowska-Rzeczycka $(1976,1978)$.

Traumatic injuries frequencies were calculated also with reference to the number of long bones (clavicula, humerus, radius, femur, tibia, fibula) - (number of examined bones/ number of affected bones $) \times 100$. The significance of the differences in frequency of traumatic injuries of long bones in the Łekno population was tested by the test for two components of the structure.

The prevalence of traumatic injuries of long bones observed in the population from Lekno was compared with the simillar data from the selected populations from Central Europe - Slavonic population from the Czech Republic (Pohansko u Břeclavi; $8^{\text {th }}-10^{\text {th }}$ centuries AD) (Kanášová et al. 2009), late medieval - early modern $\left(11^{\text {th }}-19^{\text {th }}\right.$ centuries AD) populations from Serbia (Velemirovi Drovi, Stara Torina, Dići, Čačak, Valjevska Gračanica, Žiča) (Djurić et al. 2006) and a medieval $\left(13^{\text {th }}-14^{\text {th }}\right.$ centuries AD) population from Croatia (Kaprivno) (Novak 2011). The significance of the differences between popultions was tested by the test for two components of the structure.

The significance of differences was determined at the 0.05 probability level. All computations and charts were made using Statistica 9.0 PL software. 


\section{Results}

Evidence of traumatic injuries in Łekno population was found in 30 individuals (23 males and 7 females). All of the individuals with bone injuries were adults. The prevalence of fractures in the population from the Łekno site is shown in Table 1.

Table 1. Frequencies of traumatic injuries in the Lekno population.

\begin{tabular}{ccccccccc}
\hline \multicolumn{3}{c}{ Males } & \multicolumn{3}{c}{ Females } & \multicolumn{3}{c}{ Total* $^{*}$} \\
\hline $\mathbf{N}$ & $\mathbf{N}_{1}$ & $\mathbf{\%}$ & $\mathbf{N}$ & $\mathbf{N}_{1}$ & $\mathbf{\%}$ & $\mathbf{N}$ & $\mathbf{N}_{1}$ & $\mathbf{\%}$ \\
\hline 147 & 23 & 15.6 & 81 & 7 & 8.6 & 247 & 30 & 12.1 \\
\hline
\end{tabular}

$\mathrm{N}$ - number of examined individuals; $\mathrm{N}_{1}$ - individuals affected; $\%$-frequency of affected individuals; * total number of examined individuals (males, females, unsexed).

The test of differences between two components of the structure showed no significant differences between females and males with regard to the frequency of traumatic injuries $(\mathrm{p}=0.134)$.

Overall injury frequencies in the populations from Łekno, Cedynia, Czersk, Złota Pińczowska, Toruń, Słaboszewo and Doktorce are compiled in Table 2. The overall frequency of traumatic injuries in the Lekno population is $12.1 \%$. The highest frequency of injuries was noted for the populations from Doktorce (14.0\%) and Słaboszewo (13.2\%), while the lowest frequencies of traumas were observed in the populations from Czersk (4.3\%), Cedynia (4.2\%) and Złota Pińczowska (3.45\%) (Table 2).
The frequency of injuries for the Łekno population differs significantly from frequencies for the populations from Czersk, Cedynia and Złota Pińczowska (these being the populations with the lowest frequencies of traumatic injuries noted) while it does not differ from the frequencies for the Toruń, Słaboszewo and Doktorce populations (Table 3).

Doktorce, Słaboszewo and Toruń sites do not differ significantly between one another in terms of prevalence of injuries. Likewise, Czersk, Cedynia and Złota Pińczowska are populations with similar frequencies of injuries found - differences between them are not statistically significant (Table 3).

Next, the frequencies of traumatic injuries in the Łekno population were compared with frequencies of injuries in populations from the Czech Republic (Kanášová et al. 2009), Serbia (Djurić et al. 2006) and Croatia (Novak 2011). Table 4 shows the frequencies of traumatic injuries by long bones (clavicula, humerus, radius, ulna, femur, tibia and fibula) in the Łekno population.

In the examined population clavicula, ulna and fibula(exept females) are the most affected bones (Table 4). Table 5 shows the results regarding differences between various bones in terms of frequency of traumatic injuries in the Łekno population.

In the studied population differences in the frequency of traumatic injuries were found only for upper extremity bones. In terms of the number of traumatic injuries present the clavicula differs significantly from humerus and from radius. The frequency of injuries on the humerus is different than the frequency for the ulna. Also the radius and ulna differ from each other in this respect (Table 5).

Table 2. Frequency of traumatic injuries by cemetery site*.

\begin{tabular}{|c|c|c|c|c|}
\hline Cemetery & $\mathbf{N}$ & $\mathbf{N}_{1}$ & $\%$ & Source \\
\hline Cedynia $\left(10^{\text {th }}-14^{\text {th }}\right.$ centuries AD) & 286 & 12 & 4,2 & Abramczyk (1993) \\
\hline Złota Pińczowska $\left(11^{\text {th }}-12^{\text {th }}\right.$ centuries AD) & 147 & 5 & 3.4 & Komitowski (1975) \\
\hline Czersk $\left(11^{\text {th }}-3^{\text {th }}\right.$ centuries AD $)$ & 531 & 23 & 4.3 & Gładykowska-Rzeczycka $(1976,1978)$ \\
\hline Lekno $\left(13^{\text {th }}-16^{\text {th }}\right.$ centuries AD) & 247 & 30 & 12.1 & This study \\
\hline Torun $\left(12^{\text {th }}-6^{\text {th }}\right.$ centuries AD) & 216 & 18 & 8.3 & Jakubowska, Kozłowski (2011) \\
\hline Słaboszewo $\left(14^{\text {th }}-17^{\text {th }}\right.$ centuries AD) & 105 & 14 & 13.2 & Tukałło et al. (1974) \\
\hline Doktorce (Middle Ages) & 42 & 6 & 14.0 & Gładykowska-Rzeczycka (1976, 1978) \\
\hline
\end{tabular}

$\mathrm{N}$ - number of examined individuals; $\mathrm{N}_{1}$ - individuals affected; \% - frequency of individuals affected; * analysis for all of examined group (males, females and unsexed).

Table 3. Differences in traumatic injuries by cemetery site**.

\begin{tabular}{|c|c|c|c|c|c|c|}
\hline Cemetery & Lekno & Cedynia & Czersk & Zlota P. & Toruń & Staboszewo \\
\hline \multicolumn{7}{|l|}{ Łekno } \\
\hline Cedynia & $0.0008 *$ & & & & & \\
\hline Czersk & $0.0001 *$ & 0.9462 & & & & \\
\hline Złota P. & $0.0034 *$ & 0.6849 & 0.6265 & & & \\
\hline Toruń & 0.1801 & $0.0413 *$ & $0.0291 *$ & 0.0596 & & \\
\hline Słaboszewo & 0.7642 & $0.0015 *$ & $0.0004 *$ & $0.0036^{*}$ & 0.1995 & \\
\hline Doktorce & 0.7222 & $0.0090 *$ & $0.0055^{*}$ & $0.0093 *$ & 0.2429 & 0.8977 \\
\hline
\end{tabular}

$\mathrm{p}$ - values calculated using the test of differences for two components of the structure; * difference statistically significant at the 0.05 level; ** analysis for all of examined group (males, females and unsexed). 
Table 4. Frequencies of traumatic injuries by long bones in the Łekno population.

\begin{tabular}{lcrrrrrrrr}
\hline \multirow{2}{*}{ Bone } & \multicolumn{3}{c}{ Both sexes + unsexed } & \multicolumn{3}{c}{ Males } & \multicolumn{3}{c}{ Females } \\
\cline { 2 - 11 } & $\mathbf{n}$ & $\mathbf{n}_{\mathbf{1}}$ & $\mathbf{\%}$ & $\mathbf{n}$ & $\mathbf{n}_{\mathbf{1}}$ & $\mathbf{\%}$ & $\mathbf{n}$ & $\mathbf{n}_{\mathbf{1}}$ & $\mathbf{\%}$ \\
\hline Clavicle & 195 & 7 & 3.6 & 131 & 5 & 3.8 & 55 & 2 & 3.6 \\
Humerus & 242 & 1 & 0.41 & 165 & 1 & 0.61 & 74 & 0 & 0.0 \\
Radius & 211 & 1 & 0.5 & 152 & 1 & 0.66 & 56 & 0 & 0.0 \\
Ulna & 170 & 6 & 3.53 & 112 & 4 & 3.57 & 51 & 2 & 3.92 \\
Femur & 223 & 2 & 0.9 & 139 & 1 & 0.72 & 76 & 1 & 1.3 \\
Tibia & 241 & 3 & 1.24 & 151 & 2 & 1.32 & 77 & 1 & 1.3 \\
Fibula & 133 & 3 & 2.26 & 81 & 3 & 3.7 & 40 & 0 & 0.0 \\
Total & 1415 & 23 & 1.64 & 931 & 17 & 1.86 & 471 & 6 & 1.27 \\
\hline
\end{tabular}

$\mathrm{n}$ - number of examined bones; $\mathrm{n}_{1}-$ number of bones fractured.

Table 5. Differences in frequency of traumatic injuries of long bones in the Łekno population (males, females and unsexed individuals together).

\begin{tabular}{lllllll}
\hline \multirow{2}{*}{ Bone } & \multicolumn{5}{c}{$\mathbf{p}$} \\
\cline { 2 - 6 } & Clavicula & Humerus & Radius & Ulna & Femur & Tibia \\
\hline Clavicula & & & & & \\
Humerus & $0.0135^{*}$ & & & & \\
Radius & $0.0254^{*}$ & 0.8867 & & & & \\
Ulna & 0.9713 & $0.0458^{*}$ & $0.0292^{*}$ & & & \\
Femur & 0.0544 & 0.5096 & 0.6188 & 0.0675 & & \\
Tibia & 0.1018 & 0.3468 & 0.4045 & 0.1180 & 0.7229 & \\
Fibula & 0.4888 & 0.0952 & 0.1411 & 0.5183 & 0.2921 & 0.4521 \\
\hline
\end{tabular}

$\mathrm{p}$ - values calculated using the test for two components of the structure; * difference statistically significant at the 0.05 level; ** analysis for all of examined group (males, females and unsexed).

Table 6. Frequencies of traumatic injuries of long bones (clavicula, humerus, radius, ulna, femur, tibia and fibula) by cemetery site*.

\begin{tabular}{lcccl}
\hline Cemetery & $\mathbf{n}$ & $\mathbf{n}_{1}$ & $\mathbf{\%}$ & \multicolumn{1}{c}{ Source } \\
\hline Łekno $\left(13^{\text {th }}-16^{\text {th }}\right.$ centuries AD) & 1415 & 23 & 1.64 & This paper \\
Czech Republic $\left(8^{\text {th }}-10^{\text {th }}\right.$ centuries AD) & 1866 & 26 & 1.39 & Kanášová et al. $(2009)$ \\
Serbia $\left(11^{\text {th }}-19^{\text {th }}\right.$ centuries AD) & 2801 & 20 & 0.70 & Djurić et al. $(2006)$ \\
Croatia $\left(13^{\text {th }}-14^{\text {th }}\right.$ centuries AD) & 211 & 4 & 1.90 & Novak $(2011)$ \\
\hline
\end{tabular}

$\mathrm{n}$ - number of bones; $\mathrm{n}_{1}$ - number of affected bones; * analysis for all of examined group (males, females and unsexed).

Table 7. Differences between total traumatic injuries of long bones (clavicula, humerus, radius, ulna, femur, tibia and fibula) in various populations**

\begin{tabular}{lccc}
\hline \multirow{2}{*}{ Cemetery } & \multicolumn{3}{c}{$\mathbf{p}$} \\
\cline { 2 - 4 } & Lekno & Czech Republic & Serbia \\
\hline Lekno & & & \\
Czech Republic & 0.5593 & & \\
Serbia & $0.004^{*}$ & $0.0174^{*}$ & 0.0567 \\
Croatia & 0.7836 & 0.5558 & 0.00 \\
\hline
\end{tabular}

$\mathrm{p}$ - values calculated using the test for two components of the structure; * difference statistically significant at the 0.05 level; ** analysis for all of examined group (males, females and unsexed).

Frequencies of injuries for the populations from Łekno, Czech Republic, Serbia and Croatia are shown in Table 6. The lowest frequency of traumatic injuries was observed in the populations from Serbia $(0.7 \%)$, while the highest frequency was recorded for the population from Croatia $(1.9 \%)$ (Table 6).
In terms of the frequency of traumatic injuries, the Łekno population differs significantly from the populations from Serbia but it does not differ from the populations from the Czech Republic and Croatia. Populations from Serbia and the Czech Republic differ with regard to the frequency of traumatic injuries $(\mathrm{p}=0.0174)$ (Table 7).

\section{Discussion}

In terms of the frequency of injuries the population from Łekno is not significantly different from other medieval groups from the area of Poland.

Low percentage of traumatic injuries both in the Łekno population and in the medieval groups from the area of Poland used for comparison allows us to presume that these populations led a quiet life, and the injuries suffered by individuals were mostly of an accidental nature. 
The traumatic injuries observed in the analyzed groups from the area of Poland do not correspond with the data on selected health status indicators. Among the studied groups the highest frequency of cribra orbitalia (27\%) was observed in the population from Cedynia (Piontek et al. 2001) (a population with low frequency of traumatic injuries $-4.2 \%$ ). Piontek et al. (2001) found $23 \%$ frequency of cribra orbitalia in the Staboszewo population (with 13\% frequency of traumatic injuries). In Doktorce, the population with the highest frequency of traumatic injuries (14\%), GładykowskaRzeczycka (1976) found cribra orbitalia in only $8 \%$ of the individuals examined. Miłosz (2000) reported the frequency of cribra orbitalia in the Łekno population at $13 \%$, while in the Czersk population cribra orbitalia was found in $4 \%$ of individuals (Gładykowska-Rzeczycka 1976).

Also the prevalence of dental carries in the populations under study is inversely proportional to the frequency of traumatic injuries, at $84 \%$ for the Lekno population (Miłosz 2000), $82 \%$ for the Słaboszewo population (Borysewicz, Otocki 1975) and 64\% for the population from Cedynia.

The Łekno population is not significantly different with regard to the frequency of traumatic injuries from other Slavonic populations from the area of Europe. In the Lekno population (Table 1), in the population from the Czech Republic (Kanášová et al. 2009) and in the contemplated Serbian population (Djurić et al. 2006) males show a higher frequency of traumatic injuries than females, and differences between females and males are not statistically significant in any of the groups. As reported by Djurić et al. (2006) males could have been more exposed to injuries from various aspects of life (interpersonal violence, hunting, activities related with agriculture etc.).

In the population from Lekno traumatic injuries were identified most often on the clavicle (3.6\%) and ulna (3.5\%) (Table 4). The fibula (2.26\%) and tibia (1.24\%) were the next most affected bones (Table 4). Again, this result is similar to the results from the Czech Republic. The ulna was the most often fractured bone in the Slavonic population from Pohansko u Břeclavi (Kanášová et al. 2009). A higher prevalence involving bones of the forearm (ulna and radius) compared to other bones was observed in other archaeological populations (e.g. Grauer, Roberts 1996). In the populations from Serbia, the fibula was the most affected bone, with ulna in the second place (Djurić et al. 2006). Fibula was also the most affected bone in the population from Croatia, with ulna and humerus next in order (Novak 2011).

In terms of the frequency of traumatic injuries the rural population from Lekno is similar to the urban population from the Czech Republic and rural population from Croatia (Tables 6,7). On the other hand, the group under study differs significantly from the rural population from Serbia $(\mathrm{p}=0.004)$ (Tables 6, 7). Also the populations from Serbia and the Czech Republic differ significantly with regard to the prevalence of traumatic injuries (Tables 7). As indicated by Kanášová et al. (2009), the differences could be a result of differences in selected samples, because Djurić et al.
(2006) included non-adult individuals in their analysis. This explanation, however, cannot be applied to the population from Łekno, as in this group also juveniles were included into the analyses. At this point it is necessary to point out to inconsistencies in the description and interpretation of trauma in the anthropological literature, which led to difficulties in comparing results of different studies (Djurić et al. (2006).

The populations from Serbia were rural groups and were mostly involved in agricultural activity (Djurić et al. 2006). As reported by Djurić et al. (2006) Serbian populations were not involved in any conflict, they were exposed to a risk of trauma only due to accidents related mainly with rural activities and, rarely, with interpersonal violence. The population from Pohansko is comparable to urban populations (Kanášová et al. 2009). As suggested by Kanášová et al. (2009) traumas in this Slavonic population were related to accidents occurring in the course of everyday life rather than to interpersonal violence.

As demonstrated by the results of this study and the results of studies by other researchers (e.g. Kanášová et al. 2009), analyses of traumatic injuries in skeletal populations are an important but insufficient source of information on the habitual behavior, occupation of the investigated groups, and on the health status or biological condition of individuals and populations.

Etiology of the traumas is usually complex (Lovell 1997; Ortner, Putschar 1981). For years, traumatic injuries have been attributed only to violence (e.g. Walker 1989; Murphy et al. 2010; Standen, Arriaza 2000; Torres-Rouff, Janqiuera 2006). Nowadays, researchers try to link the interpretation of trauma also with factors such as environmental context, and physical and cultural aspects (Judd, Roberts 1998, 1999; Larsen 1997). As reported by Judd and Roberts (1998), next to factors such as technological level, occupation, domestic violence, age (e.g. contribution of osteoporosis in increased frequency of fractures in postmenopausal females (Mensforth, Latimer 1989), reduced bone mass due to inactivity, poor health predisposition, geographic location (Kilgore et al. 1997; Lovell 1997; Scott, Buckley 2010), or even the climate also play an important role in trauma etiology. The biocultural (Scott, Buckley 2010) and sociocultural context and historical records also need to be taken into consideration in the interpretation of traumatic events (Lovell 1997).

The analysis of traumatic injuries is an important research problem of contemporary anthropology. Research results add to the existing knowledge on studied prehistoric and historic human populations. However, for their proper, more accurate interpretation it is necessary to take into account also a number of biological, cultural, social historical or environmental and other factors (Lovell 1997).

\section{Conclusions}

The frequency of traumatic injuries in the population from Łekno was $12.1 \%$. Males had more evidence of injuries than females (the difference was not statistically significant). 
Injuries were more common on the upper extremities than in other skeletal parts. The bones most exposed to injury were the clavicula and ulna.

In the population from Łekno the frequency of traumatic injuries is similar to the frequency in the rural population from Doktorce, Słaboszewo and to the urban population from Torun, but it differs from the rural populations from Czersk, Cedynia and Złota Pińczowska.

In terms of traumatic injuries to long bones the Lekno population does not differ from urban populations from the Czech Republic and the rural population from Croatia, but it differs from the agricultural populations from Serbia.

Analyses of traumatic injuries in skeletal populations are not a sufficient source of information on occupation, health or biological condition of individuals or populations.

\section{Acknowledgments}

This study was supported by the Polish Ministry of Science and Higher Education; contract grant number: N N303 600239 .

\section{References}

ABRAMCZUK, A. 1993: Analiza częstości występowania zmian pourazowych w serii szkieletowej $\mathrm{z}$ wczesnośredniowiecznego cmentarzyska w Cedyni (unpublished).

BORYSEWICZ, M., OTOCKI, P. 1975: Próchnica zębów u dawnej ludności ze Słaboszewa, Kołobrzegu i Chełmskiej Góry (XII-XVIII w.), Przegląd Antropologiczny 41/2, 311-330.

BRASILI, P., BIANCHI, E., VENTRELLA, R. 2004: Traumatic events and Life-Style in Ancient Italian Populations, Coll Anthropol 28, 179-191.

BUIKSTA, J. E., UBELAKER, D. H. 1994: Standards for Data Collection from Human Skeletal Remains. Arkansas Archeological Survey Research 44

DJURIĆ, M. P., ROBERTS, C. A., RAKOČEVIĆ, Z. B., DJONIĆ, D. D., LEŠIC, A. R. 2006: Fractures in Late Medieval Skeletal Populations From Serbia, American Journal of Physical Anthropology 130, 167-178.

FEREMBACH, D., SCHWIDETZKY, I., STLOUKAL, M. 1979 : Empfehlungen für die Alters- und Geschlechtsdiagnose am Skelett, Homo 30, 1-32.

GŁADYKOWSKA-RZECZYCKA, J. 1976: Zmiany w układzie kostnym ludności ze średniowiecznych cmentarzysk, Badania populacji ludzkich na materiałach współczesnych i historycznych, Seria Antropologia UAM 4, 85-103.

GŁADYKOWSKA-RZECZYCKA， J. 1978: Częstość występowania niektórych zmian chorobowych widocznych w obrębie układu kostnego na przestrzeni tysiącleci, Przeglad Antropologiczny 44/2, 410-415.

GRAUER, A., ROBERTS, C. 1996: Paleoepidemiology, healing, and possible treatment of trauma in the medieval cemetery populations of St. Helen-on-the-Walls, York, England, American Journal of Physical Anthropology 100, 531-544.

JAKUBOWSKA, G. J., KOZŁOWSKI, T. 2011: Trauma - life and death in the medieval city of Torun', Poland. American Journal of Physical Anthropology 144/2, Supplement.

JUDD, M. A. 2002: Comparison of long bone trauma recording methods. Journal of Archaeological Science 29, 1255-1265.

JUDD, M. A., ROBERTS, C. A. 1998: Fracture Patterns at the Medieval Leper Hospital in Chichester, American Journal of Physical Anthropology 105, 43-55.

JUDD, M. A., ROBERTS, C. A. 1999: Fracture Trauma in a Medieval British Farming Village, American Journal of Physical Anthropology 109, 229-243.
JURMAIN, R. 2001: Paleoepidemiolgical patterns of trauma in a prehistoric population from central California, American Journal of Physical Anthropology 115, 13-23.

KANÁŠOVÁ, K., DROZDOVÁ, E., SMRČKA, V. 2009: Fracture trauma in Slavonic population from Pohansko u Břeclavi (Czech Republic), Anthropologie 47/3, 243-252.

KILGORE, L., JURMAIN, R., GERVEN, D. 1997: Paleoepidemiological Patterns of Trauma in a Medieval Nubian Skeletal Population, International Journal of Osteoarchaeology 7, 103-114.

KOMITOWSKI, D. 1975: Badania paleopatologiczne szczątków kostnych z wczesnośredniowiecznego cmentarzyska w Złotej Pińczowskiej, Wiadomości Archeologiczne 40/1, 113-118.

KOZŁOWSKI, T., JANOWSKA, N., KRAJEWSKA, M., DROZD, A. 2011: Zmiany patologiczne i struktura schorzeń średniowiecznych mieszkańców Torunia. In: First Meeting on Paleopathology. Nicolaus Copernicus University, 51-60.

LARSEN, C. S. 1987: Bioarchaeological Interpretations of Subsistence Economy and Behavior from Human Skeletal Remains. In: M. B. Schiffe (ed.): Advances in Archaeological Method and Theory. San Diego, Academic Press, 339-445.

LARSEN, C. S. 1997: Bioarchaeology. Interpreting behavior from the human skeleton. Cambridge University Press, Cambridge, UK.

LOVEJOY, C. O., HAIPLE, K. G. 1981: The analysis of fractures in skeletal populations with the example from the Libben Site, Ottawa Country, Ohio, American Journal of Physical Anthropology 55, 529-541.

LOVELL, N. 1997: Trauma Analysis in Paleopathology, Yearbook of Physical Anthropology 40, 139-170.

MENSFORTH, R. P., LATIMER, B. M. 1989: Hamann-Todd collection aging studies. Osteoporosis fracture syndrome, American Journal of Physical Anthropology 80, 461-479.

MIŁOSZ, E. 2000: Kondycja biologiczna późnośredniowiecznej populacji z Łekna. In: A. M. Wyrwa (ed.): Studia i materiały do pradziejów Pałuk. Środowisko naturalne i osadnictwo w tekneńskim kompleksie osadniczym. 405-418.

MIŚKIEWICZ, M. 1967: Cmentarzysko wczesnośredniowieczne w Złotej Pinczowskiej, pow. Pińcz. Rozprawy Zespołu Badań nad Polskim Średniowieczem. UW i PW 4, Warszawa.

MIŚKIEWICZ, M 1968: Cmentarzysko wczesnośredniowieczne w Złotej Pińczowskiej, pow. Pińcz. (Sprawozdanie z czterech lat badań (19641965). Sprawozdania. Zespół do Badań nad Polskim Średniowieczem. UW i PW, Warszawa.

MURPHY, M. S., GAITHER, C., GOYCOCHEA, E., VERANO, J. W., COCK, G. 2010: Violence and weapon-related trauma at PuruchucoHuaquerones, Peru, American Journal of Physical Anthropology 142, 636-649.

NEVES, W. A., BARROS, A. M., COSTA, M. A. 1999: Incidence and distribution of postcranial fractures in the prehistoric population of San Pedro de Atacama, Northern Chile, American Journal of Physical Anthropology 100, 253-258.

NOVAK, M. 2011: Bioarcheoological analysis of the human skeletal remains from the late mediaeval cemetery of Koprinovo, Southern Croatia, Bulletin of the International Association for Paleodontology 5/1, $13-23$.

ORTNER, D. J., PUTSCHAR, W. G. 1981: Identification of pathological conditions in human skeletal remains. Smithsonian Contributions to Anthropology. Smithsonian Institution Press, Washington, DC, 28.

PAINE, R. R., MANCINELli, D., RUGGIERI, M., COPPA, A. 2007: Cranial trauma in Iron Age Samnite Agriculturists, Alfedena, Italy: Implications for biocultural and economic stress, American Journal of Physical Anthropology 132, 48-58.

PIEKARZ, I., PIONTEK, J. 1999: Zmiany zwyrodnieniowe kręgostupa $w$ populacji średniowiecznej (XIX-XVII w.) ze Staboszewa. Monografie Instytutu Antropologii UAM, Poznań 5.

PIONTEK, J., HENNEBERG, M. 1981: Mortality changes in a Polish rural community (1350-1972) and estimation of their evolutionary significance, American Journal of Physical Anthropology 54, 129-138.

PIONTEK, J., SEGEDA, S., JERSZYŃSKA, B. 2001: Cribra orbitalia in medieval populations from Ukraine, Anthropologie 39, 143-149.

PORZEZIŃSKI,A. 2006: Wczesnośredniowieczne cmentarzysko szkieletowe na stanowisku $2 a$ w Cedyni, województwo zachodniopomorskie. Biblioteka Naukowa Muzeum Narodowego, Szczecin. 
RAUGHT, J. 1976: Czersk we wczesnym średniowieczu. Zakład im. Ossolińskich, Wydawnictwo PAN.

SCOTT, R. M., BUCKLEY, H. R. 2010: Biocultural interpretations of trauma in two prehistoric Pacific island populations from Papua New Guinea and Solomon Island, American Journal of Physical Anthropology $142,509-518$

STANDEN, V. G., ARRIAZA, B. T. 2000: Trauma in the preceramic coastal populations of Northern Chile: Violence or occupational hazards? American Journal of Physical Anthropology 112, 239-249.

ŠLAUS, M., NOVAK, M. 2006: An analysis of traumas in medieval samples from Kliškovac and Crkvari, Prilozi Instituta za Arheolgiju u Zagrebu 23, 213-228.

TORRES-ROUFF. C., JUNQUIERA, M. A. C. 2006: Interpersonal violence in prehistoric San Pedro de Atacama, Chile: Behavioral implications of environmental stress, American Journal of Physical Anthropology 130, $60-70$.
TUKAŁŁO, K., KOSICKI, W., KOZIEROWSKI, M., KRAWCZYŃSKI, W. 1974: Badania układu kostno-stawowego ludności wielkopolskiej żyjącej w okresie od XV do XVII wieku, Chirurgiia Narządu Ruchu, Ortop Pol 39/1, 73-79.

WALKER, P. L. 1989: Cranial injuries as evidence of violence in prehistoric southern California, American Journal of Physical Anthropology 80, 313-323.

WIERCIŃSKA, A. 1980: Zmienność cech typów budowy ciała w ciągu ostatniego tysiąclecia na podstawie materiału szkieletowego z Wiślicy, Materialy i prace antropologiczne 98, 133-203.

WYRWA, A. M. 1989: Informacje źródłowe i historia badań stanowiska $\mathrm{nr} 3 \mathrm{w}$ Łeknie od translokacji do początku stacjonarnych badań wykopaliskowych. In: A. M. Wyrwa (ed.): Studia i materiaty do dziejów Paluk 1. Poznań, 105-120.

WYRWA, A. M. 2003: Klasztor cysterski w teknie (polowa XII - koniec XIV wieku): zarys dziejów. Łekno, Poznan. 
